\title{
Growth factor progranulin blocks tumor necrosis factor- $\alpha$-mediated inhibition of osteoblast differentiation
}

\author{
N. Wang ${ }^{1}$, J. Zhang ${ }^{1}$ and J.X. Yang ${ }^{2}$ \\ ${ }^{1}$ Department of Rehabilitation, Linyi People's Hospital, Linyi, China \\ ${ }^{2}$ Department of Orthopedics, Linyi People's Hospital, Linyi, China \\ Corresponding author: J.X. Yang \\ E-mail: yangjianxun10281@163.com
}

Genet. Mol. Res. 15 (3): gmr. 15038126

Received December 17, 2015

Accepted January 15, 2016

Published September 9, 2016

DOI http://dx.doi.org/10.4238/gmr.15038126

Copyright (C) 2016 The Authors. This is an open-access article distributed under the terms of the Creative Commons Attribution ShareAlike (CC BY-SA) 4.0 License.

\begin{abstract}
Tumor necrosis factor- $\alpha$ (TNF- $\alpha$ ) stimulates osteoclast differentiation and suppresses osteoblast differentiation, leading to bone loss and decreased bone mass in local inflammation areas in patients with rheumatoid arthritis. The growth factor progranulin (PGRN) is expressed in various types of cells and play crucial roles in the pathogenesis of atherosclerosis and arthritis by blocking TNF- $\alpha$. Here, we investigated the role of PGRN in blocking TNF- $\alpha$-mediated inhibition of osteoblast differentiation and the regulatory mechanism. $\mathrm{C} 2 \mathrm{C} 12$ stem cell was induced by bone morphogenetic protein-2 (BMP2) for osteoblast differentiation. A significant increase in ALP activity $(\mathrm{P}<0.001)$, as well as the expression of ColI, Ocn, and Bsp in the induced cells $(\mathrm{P}<0.01$ and $\mathrm{P}<0.001)$ were observed; the marker gene expression and ALP activity were inhibited by TNF- $\alpha(\mathrm{P}<0.01$ and $\mathrm{P}$ $<0.001)$. PGRN significantly blocks the TNF- $\alpha$-mediated inhibition of osteoblast differentiation, evidenced by the ALP activity $(\mathrm{P}<0.05$ and
\end{abstract}


$\mathrm{P}<0.01$ ), Alizarin red staining, the expression of ColI, Ocn, and Bsp $(\mathrm{P}<0.05$ and $\mathrm{P}<0.01)$ and the osteoblast key transcription factor gene Runx2 (P $<0.01)$, Osx $(\mathrm{P}<0.05)$, and ATF4 $(\mathrm{P}<0.05)$. Mechanical study indicated that PGRN significantly blocks the TNF- $\alpha$-mediated stimulation of NF- $\kappa B$ signaling $(\mathrm{P}<0.01$ and $\mathrm{P}<0.001)$. PGRN exerts a protective effect on osteoblast differentiation in an inflammatory environment. Thus, we concluded that the treatment of osteoblasts with PGRN could be used in the future to prevent or treat rheumatoid arthritis-associated bone loss.

Key words: Tumor necrosis factor- $\alpha$; Growth factor progranulin; Osteoclast; Differentiation; Rheumatoid arthritis

\section{INTRODUCTION}

Osteoblasts, one of the main cells in the bone tissue, are derived from mesenchymal stem cells (MSCs) that comprise the bone tissue. MSCs have multiple differentiation potentials, and can differentiate into chondrocytes, osteoblasts, and adipocytes (Uccelli et al., 2008). Accurate regulation of osteoblast differentiation, which relies on proper extracellular signal stimulation and appropriate expression of osteogenic transcription factors, plays a crucial role in the process of bone development and osteoblast remodeling during the embryonic stage (Zaidi, 2007). The key cellular regulatory signals identified so far include bone morphogenetic proteins (BMPs), wingless-ints, and Notch (Huang et al., 2007); several key transcription factors of osteoblast differentiation, including Runt-related transcription factor 2 (Runx2), Osterix (Osx), and activating transcription factor 4 (ATF4) (Karsenty et al., 2009) have also been identified.

Rheumatoid arthritis (RA) is a chronic systemic disease characterized by inflammatory synovitis (Goldring and Gravallese, 2000). Pathological studies have indicated that tumor necrosis factor (TNF)- $\alpha$ plays a critical role in the pathogenesis of RA (Azuma et al., 2000; Baum and Gravallese, 2014). A number of studies have reported the strong inhibitory effect of TNF- $\alpha$ on osteoblast differentiation of MSCs (Walsh et al., 2009; Walsh and Gravallese, 2010). Early in vitro experiments indicated that TNF- $\alpha$ inhibits the differentiation of preosteoblasts into mature osteoblasts (Canalis, 1987). Moreover, the recent "TNF- $\alpha$ receptor gene excluding p55 knockout" experiment proved that TNF- $\alpha$ reduces the peak bone mass in mice (Gilbert et al., 2000; Li et al., 2007). Previous studies have shown that TNF- $\alpha$ inhibits osteoblast differentiation by activating the downstream signal pathway of nuclear factor- $\kappa \mathrm{B}$ (NF- $\kappa B$ ) (Chang et al., 2009). Therefore, the inhibition of TNF- $\alpha$ on osteoblast differentiation of MSCs has been studied extensively.

Progranulin (PGRN) is a growth factor containing 593 amino acids. A recent study described the protective effect of PGRN on Alzheimer's disease, as well as its positive role in wound healing (He et al., 2003; Pereson et al., 2009). Further studies have reported that PGRN inhibits TNF- $\alpha$ and plays a key role in the pathogenesis of atherosclerosis and rheumatoid arthritis (Liu, 2011; Tang et al., 2011; Hwang et al., 2013). However, the exact effects of PGRN on bone tissue remain to be validated. Studies have indicated that PGRN promotes endochondral ossification during the development and control of bone repair, by regulating the expression of BMP as well as TNF- $\alpha$ signaling (Zhao et al., 2013). Recent studies have

Genetics and Molecular Research 15 (3): gmr.15038126 
indicated that PGRN inhibits TNF- $\alpha$-mediated osteoclast differentiation and directly promotes osteoblast differentiation (Noguchi et al., 2015). However, the possible role of PGRN in blocking the TNF- $\alpha$-mediated inhibition of osteoblast differentiation remains to be reported.

Here, based on the BMP-2-induced mesenchymal stem cell line $\mathrm{C} 2 \mathrm{C} 12$ osteoblast differentiation model, we determined that PGRN significantly blocks the TNF- $\alpha$-mediated inhibition of osteoblast differentiation and exerts a protective effect on osteoblast differentiation under inflammatory conditions. We speculate that this effect could be used to develop novel methods for the prevention and treatment of rheumatoid arthritis-induced osteoporosis.

\section{MATERIAL AND METHODS}

\section{Materials}

The materials used in our study included C2C12 cells (ATCC, Manassas, VA, USA), Dulbecco's modified Eagle's medium (DMEM; Gibco, Invitrogen, Carlsbad, CA, USA), fetal bovine serum (FBS; Hyclone, GE Healthcare, Little Chalfont, UK), $0.25 \%$ trypsin-EDTA (Gibco, Invitrogen), reverse transcriptase (Fermentas, Waltham, MA, USA), SYBR ${ }^{\circledR}$ Premix $\mathrm{Ex} \mathrm{Taq}^{\mathrm{TM}}$ (TaKaRa, Otsu, Japan), luciferase reporter gene plasmid pGL4.32[luc2P/NF-кBRE/Hygro] and pRL Renilla luciferase (Promega, Madison, WI, USA), pNPP (Sigma-Aldrich, St. Louis, MO, USA), alizarin red (Sigma-Aldrich), luciferase quantitative test kits (Promega), and BMP-2 and PGRN (R\&D Systems, Minneapolis, MN, USA).

\section{Methods}

\section{Modeling osteoblast differentiation in C2C12 cells}

C2C12 cells were cultured with DMEM supplemented with $10 \%$ FBS under relatively humid conditions $\left(37^{\circ} \mathrm{C}, 5 \% \mathrm{CO}_{2}\right)$. Directional differentiation of cells seeded on 12-well plates into osteoblasts (induction culture) was induced by introducing $100 \mathrm{ng} / \mathrm{mL}$ BMP-2. The cells were then treated with various concentrations of PGRN. Induced differentiation time was determined through specific experimental arrangements. ColI (type I procollagen), Ocn (osteocalcin), and Bsp (bone protein) expression was confirmed by real-time polymerase chain reaction (PCR). Alizarin red staining was used to determine the mineralization, and quantitative ALP analysis was used to confirm the ALP activity in the $\mathrm{C} 2 \mathrm{C} 12$ cell osteoblast differentiation model.

\section{Quantitative PCR}

Total RNA was extracted using TRIzol reagent, according to the experimental procedures provided by the manufacturer. cDNA reverse transcription was conducted in a $25-\mu \mathrm{L}$ system using the total RNA as the primer and M-MLV reverse transcriptase. The fluorescent quantitative PCR system, prepared using the SYBR ${ }^{\circledR}$ Premix Ex Taq ${ }^{\mathrm{TM}}$ reaction system, was composed of the following: $4.5 \mu \mathrm{L}$ ddH $_{2} \mathrm{O}, 0.1 \mu \mathrm{L} 20 \mathrm{mM}$ sense primer, $0.1 \mu \mathrm{L}$ $20 \mathrm{mM}$ antisense primer, $0.1 \mu \mathrm{L}$ cDNA, $0.2 \mu \mathrm{L}$ RoxII, and $5 \mu \mathrm{L}$ SYBR Premix. The PCR conditions were set on the ABI VIIA7 fluorescence quantitative PCR instrument as follows: denaturation at $94^{\circ} \mathrm{C}$ for $10 \mathrm{~s}, 40$ cycles of denaturation at $94^{\circ} \mathrm{C}$ for $10 \mathrm{~s}$ and annealing at $60^{\circ} \mathrm{C}$

Genetics and Molecular Research 15 (3): gmr.15038126 
for $30 \mathrm{~s}$, followed by the final melting curve program. The PCR data were analyzed using the $\mathrm{C}_{\mathrm{T}}$ attenuation value method $\left(2^{-\Delta \Delta \mathrm{Ct}}\right)$. The primer sequences used are summarized in Table 1.

Table 1. Primer sequences for real-time polymerase chain reaction.

\begin{tabular}{l|l}
\hline Genes & Primer sequences \\
\hline ColI & 5'-GAGCTGGTGTAATGGGTCCT-3' (upstream) \\
& 5'-GAGACCCAGGAAGACCTCTG-3' (downstream) \\
\hline Ocn & 5'-AAGCAGGAGGGCAATAAGGT-3' (upstream) \\
& 5'-TTTGTAGGCGGTCTTCAAGC-3' (downstream) \\
\hline Bsp & 5'-CAGGGAGGCAGTGACTCTTC-3' (upstream) \\
& 5'-AGTGTGGAAAGTGTGGCGTT-3' (downstream) \\
\hline GAPDH & 5'-GACTTCAACAGCAACTCCCAC-3' (upstream) \\
& 5'-TCCACCACCCTGTTGCTGTA-3' (downstream) \\
\hline Runx 2 & 5'-GACTGTGGTAACCGTCATGGC-3' (upstream) \\
& 5'-ACTTGGTTTTCATAACAGCGGA-3' (downstream) \\
\hline Osx & 5'-GGAAAGGAGGCACAAAGAAGC-3' (upstream) \\
\hline ATF4 & 5'-CCCCTTAGGCACTAGGAGC-3' (downstream) \\
& 5'-CCTGAACAGCGAAGTGTTGG-3' (upstream) \\
& 5'-TGGAGAACCCATGAGGTTTCAA-3' (downstream) \\
\hline
\end{tabular}

\section{Alizarin red staining and alkaline phosphatase quantitative analysis}

The culture medium was aspirated from the cell culture plate and disposed; the cells were washed twice with pre-cooled PBS. The cells were added with $4 \%$ paraformaldehyde (PFA) and were immobilized under fixed room temperature for $30 \mathrm{~s}$. The PFA was discarded and the cells were incubated with the alizarin red staining solution at $37^{\circ} \mathrm{C}$ for $45 \mathrm{~min}$. The staining solution was then removed and the cells were observed. The pNPP method was used for the quantitative analysis of alkaline phosphatase levels. The cell culture medium was aspirated, and the cells were washed twice with pre-cooled PBS. The cells were scraped into PBS solution, and centrifuged under room temperature at $12,000 \mathrm{rpm}$ for $5 \mathrm{~min}$. The supernatant was discarded and the cells were re-suspended in $300-500 \mu \mathrm{LddH}_{2} \mathrm{O}$. This was incubated at $-80^{\circ} \mathrm{C}$ for $30 \mathrm{~min}$ and in a $37^{\circ} \mathrm{C}$ water bath for $30 \mathrm{~min}$; this freeze-thaw cycle was repeated for three iterations. The cells were then centrifuged at $12,000 \mathrm{rpm}$ and $4^{\circ} \mathrm{C}$ for 30 min. The supernatant $(50 \mu \mathrm{L})$ was mixed with $50 \mu \mathrm{L}$ pNPP stock solution and $100 \mu \mathrm{L}$ DEA, and incubated in a $37^{\circ} \mathrm{C}$ water bath for $30 \mathrm{~min}$. Subsequently, $200 \mu \mathrm{L}(3 \mathrm{M}) \mathrm{NaOH}$ was added to terminate the reaction. Two hundred microliters of this solution was pipetted onto 96-well plates, and its optical density was determined at $405 \mathrm{~nm}$. The protein density was determined using the standard BCA assay kit.

\section{Cell transfection and luciferase activity assay}

Lipofectamine 2000 was used to transfect the cells with pGL4.32[luc2P/NF-kB$\mathrm{RE} /$ Hygro] and pRL Renilla luciferase plasmids. The luciferase activity was assayed using standard kits, in accordance with the experimental procedures provided by the manufacturer.

\section{Statistical analysis}

All data were statistically analyzed using SPSS v.13.0 (IBM, Armonk, NY, USA). All experiments were performed in triplicate unless otherwise noted. The data are reported as the means \pm standard deviation of three independent experiments. The data were analyzed by analysis of variance (ANOVA); pairwise comparisons were performed using the two-

Genetics and Molecular Research 15 (3): gmr.15038126 
tailed $t$-test. Three or more groups were compared using the Tukey-Kramer test. $\mathrm{P}<0.05$ was considered to be a statistically significant difference.

\section{RESULTS}

\section{Cell modeling}

The cellular model of osteoblast differentiation was established by inducing $\mathrm{C} 2 \mathrm{C} 12$ cells with BMP-2, in order to verify the capacity of PGRN in blocking the TNF- $\alpha$-mediated inhibition of osteoblast differentiation (Figure 1). We examined the osteoblast differentiation in $\mathrm{C} 2 \mathrm{C} 12$ cells following stimulation with $100 \mathrm{ng} / \mathrm{mL} \mathrm{BMP}-2$ for 7 days. We observed a significant increase in ALP activity; the ALP activity was ten times greater in the induced cells than in the control cells $(\mathrm{P}<0.001, \mathrm{~N}>3$ ) (Figure 1A). Moreover, quantitative PCR revealed a higher expression of marker genes of osteoblast differentiation (ColI, Ocn, and Bsp) in the induced cells $(\mathrm{P}<0.01, \mathrm{P}<0.001, \mathrm{~N}>3$ ) (Figure 1B). Thus, we concluded that the $\mathrm{C} 2 \mathrm{C} 12$ cell model of osteoblast differentiation was effectively established. Further, we observed a significant decrease in the marker gene expression and ALP activity in a TNF- $\alpha$-mediated osteoblast differentiation inhibition model induced by treating $\mathrm{C} 2 \mathrm{C} 12$ cells with $10 \mathrm{ng} / \mathrm{mL}$ TNF- $\alpha(\mathrm{P}<0.01, \mathrm{P}<0.001, \mathrm{~N}>3$ ) (Figure 1C and 1D), which is consistent with the results reported by previous studies.
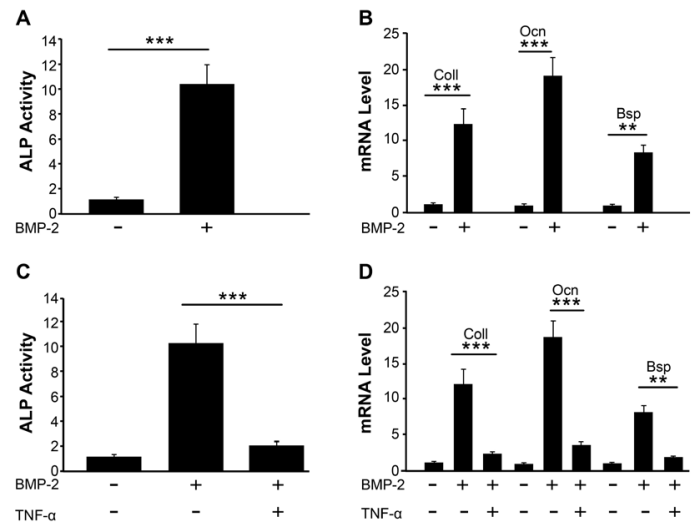

Figure 1. TNF- $\alpha$-mediated inhibition of BMP-2 induced the $\mathrm{C} 2 \mathrm{C} 12$ osteoblast differentiation cell model. A. BMP2 promotes ALP activity ( $* * * \mathrm{P}<0.001$ ); B. BMP-2 promotes the expression of ColI, Ocn, and Bsp marker genes $(* * \mathrm{P}<0.01, * * * \mathrm{P}<0.001)$; C. TNF- $\alpha$ inhibits the BMP-2-induced ALP activity $(* * * \mathrm{P}<0.001)$; D. TNF- $\alpha$ inhibits the BMP-2-induced expression of ColI, Ocn, and Bsp genes (**P $<0.01, * * * \mathrm{P}<0.001)$.

\section{PGRN blocks TNF- $\alpha$-mediated inhibition of ALP activity and mineralization}

We observed a significant increase in the ALP activity of cells treated with $50 \mathrm{ng} / \mathrm{mL}$ PGRN, $10 \mathrm{ng} / \mathrm{mL}$ TNF- $\alpha$, and $100 \mathrm{ng} / \mathrm{mL}$ BMP-2, compared to cells treated with $10 \mathrm{ng} / \mathrm{mL}$ TNF- $\alpha$ and $100 \mathrm{ng} / \mathrm{mL} \mathrm{BMP-2} \mathrm{(no} \mathrm{PGRN)}(\mathrm{P}<0.05, \mathrm{P}<0.01, \mathrm{~N}>3$ ) (Figure 2A and B). Moreover, Alizarin red staining of the 21-day induction culture showed a significant increase in the mineralization degree of cells treated with PGRN than those treated with TNF- $\alpha$ and BMP-2 alone (Figure 2C). 

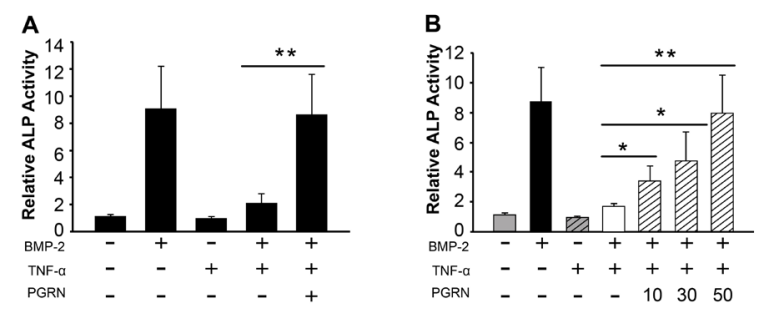

C

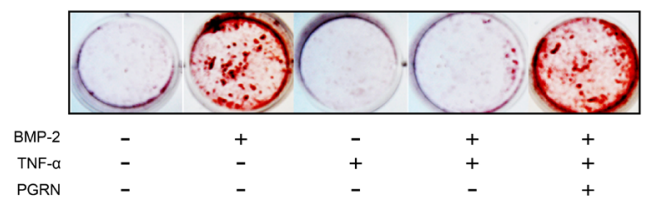

Figure 2. PGRN blocks the TNF- $\alpha$-mediated inhibition of alkaline phosphatase activity and bone mineralization. A. PGRN $(50 \mathrm{ng} / \mathrm{mL})$ blocks TNF- $\alpha$-mediated inhibition of alkaline phosphatase activity $(* * \mathrm{P}<0.01)$; B. PGRN blocks TNF- $\alpha$-mediated inhibition of alkaline phosphatase activity in a dose-dependent manner $(* \mathrm{P}<0.05$, **P $<$ $0.01)$; C. PGRN blocks the TNF- $\alpha$-mediated inhibition of bone mineralization.

\section{PGRN blocks the TNF- $\alpha$-mediated inhibition of osteoblast marker gene expression}

Quantitative PCR was used to detect the expression of osteoblast marker genes (Figure 3). We observed a significant increase in the expression of osteoblast-specific marker genes in cells treated with PGRN, compared to those treated with TNF- $\alpha$ and BMP-2 alone. Specifically, treatment with TNF- $\alpha$, BMP-2, and PGRN for 7 days led to a significant increase in the expression of ColI, Ocn, and Bsp mRNA compared to the TNF- $\alpha+B M P-2$ group $(\mathrm{P}<$ $0.05, \mathrm{P}<0.01, \mathrm{~N}>3$ ). Therefore, we concluded that PGRN significantly blocks the TNF- $\alpha$ mediated inhibition of osteoblast-specific marker gene expression.
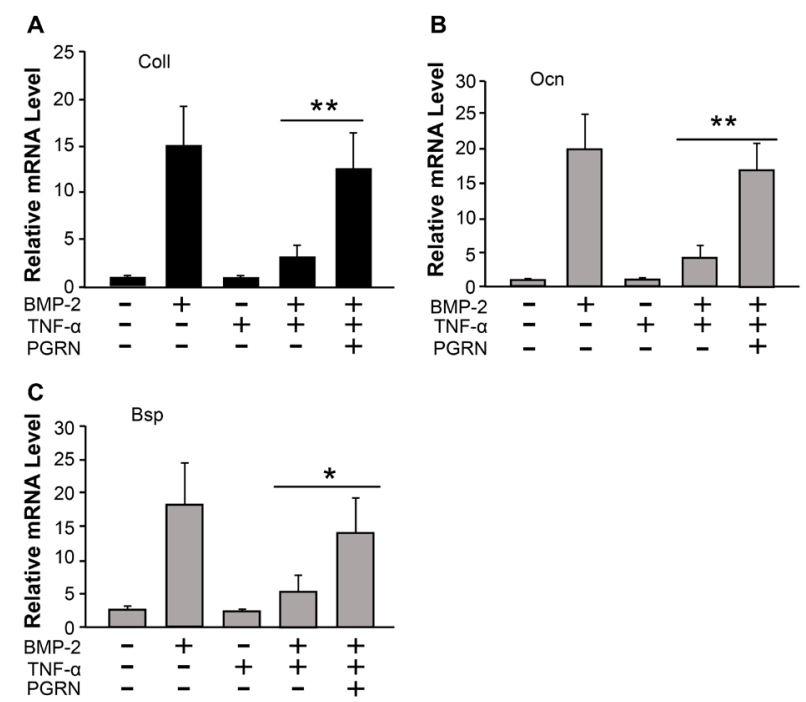

Figure 3. PGRN blocks the TNF- $\alpha$-mediated inhibition of ColI $(* * \mathrm{P}<0.01)$, Ocn $(* * \mathrm{P}<0.01)$, and Bsp $(* \mathrm{P}<$ $0.05)$ expression. 


\section{PGRN blocks the TNF- $\alpha$-mediated inhibition of Runx2, Osx, and ATF4}

We then attempted to determine the effect of PGRN on the expression of the key transcription factor genes in the osteoblast, such as Runx2, Osx, and ATF4 (Figure 4). The results of quantitative PCR indicated a significant increase in the Runx2 $(\mathrm{P}<0.01, \mathrm{~N}>3)$ (Figure 4A), Osx $(\mathrm{P}<0.05, \mathrm{~N}>3)$ (Figure 4B), and ATF4 $(\mathrm{P}<0.05, \mathrm{~N}>3)$ (Figure 4C) mRNA levels in cells treated with PGRN, in addition to TNF- $\alpha$ and BMP-2 for 7 days, compared to the cells treated in the absence of PGRN. Therefore, we concluded that PGRN significantly blocks the TNF- $\alpha$-mediated inhibition of Runx2, Osx, and ATF4 expression.
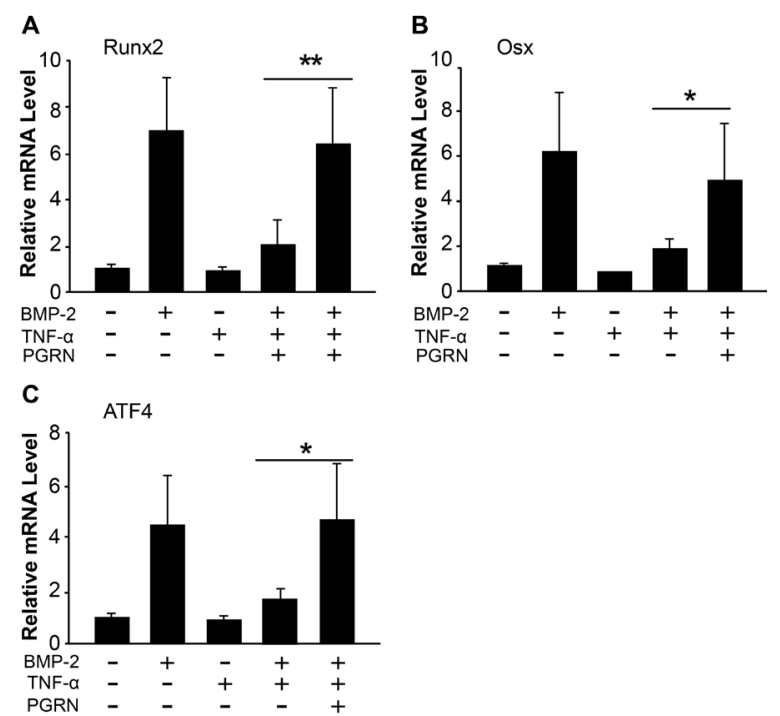

Figure 4. PGRN blocks TNF- $\alpha$-mediated inhibition of transcription factor Runx 2 , Osx, and ATF4 gene expression. Treatment with $50 \mathrm{ng} / \mathrm{mL}$ PGRN blocks the inhibitory effect of TNF- $\alpha$ on the expression of Runx2 $(\mathbf{A}, * * \mathrm{P}<0.01)$, Osx $(\mathbf{B}, * * \mathrm{P}<0.01)$, and ATF4 $(\mathbf{C}, * \mathrm{P}<0.05)$.

\section{PGRN blocks the TNF- $\alpha$-mediated NF-KB signaling}

As mentioned above, TNF- $\alpha$ inhibits osteoblast differentiation by activating the downstream NF- $\mathrm{KB}$ signaling pathway. Here, we attempted to determine the exact mechanism with which PGRN blocks TNF- $\alpha$-mediated inhibition of osteoblast differentiation. We speculated that PGRN blocks the activation of TNF- $\alpha$ induced NF- $\kappa B$ signaling in order to block TNF- $\alpha$-mediated inhibition of osteoblast differentiation. We used a fluorescent reporter gene assay and western blot to verify the regulatory effect of PGRN on NF- $\kappa B$ signaling (Figure 5). $\mathrm{C} 2 \mathrm{C} 12$ cells were transfected with the pGL4.32[luc2P/NF-kB-RE/Hygro] plasmid, and the luciferase activity was determined after PGRN treatment for $24 \mathrm{~h}$; we observed a significant increase in luciferase activity in the TNF- $\alpha+$ BMP- 2 treatment group, while the TNF- $\alpha+$ BMP$2+\mathrm{PGRN}$ treatment group showed luciferase inhibition in a PGRN concentration-dependent manner $(\mathrm{P}<0.01, \mathrm{P}<0.001, \mathrm{~N}>3$ ) (Figure 5A). We also measured the luciferase activity in $\mathrm{C} 2 \mathrm{C} 12$ cells at different time points. We observed a significant decrease in the luciferase activity in PGRN-treated cells after $24(\mathrm{P}<0.001, \mathrm{~N}>3)$ (Figure 5B) and $48 \mathrm{~h}(\mathrm{P}<0.001$, 
$\mathrm{N}>3$ ) (Figure 5C), compared to the TNF- $\alpha+\mathrm{BMP}-2$ group. This result indicated that PGRN significantly blocks the activation of TNF- $\alpha$ induced downstream NF- $\mathrm{BB}$ signaling.

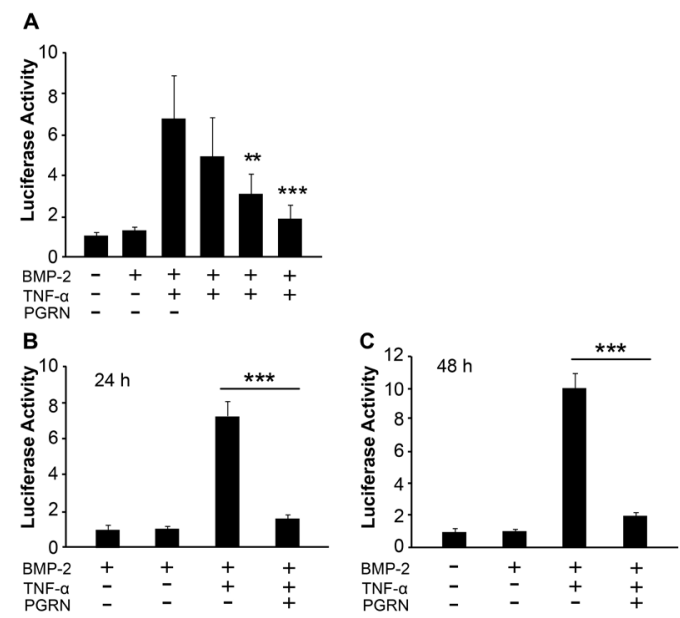

Figure 5. PGRN blocks the TNF- $\alpha$-induced activation of NF- $\kappa B$ signaling. A. PGRN blocks the TNF- $\alpha$-induced activation of NF- $\mathrm{KB}$ luciferase activity in a dose-dependent manner $(* * \mathrm{P}<0.01$, $* * * \mathrm{P}<0.001)$; treatment with $50 \mathrm{ng} /$ $\mathrm{mL}$ PGRN for 24 (B) and 48 (C) h blocks the TNF- $\alpha$-induced activation of NF- $\kappa \mathrm{B}$ luciferase activity $(* * * \mathrm{P}<0.001)$.

\section{DISCUSSION}

RA is a serious threat to human health that causes excessive secretion of the inflammatory cytokine TNF- $\alpha$ to the local inflammatory sites, which initiates a series of inflammatory reactions that ultimately leads to bone loss and decrease in bone mass. On one hand, TNF- $\alpha$ stimulates osteoclast differentiation to promote bone resorption to combat the decrease in bone mass and density, while on other, it suppresses osteoblast differentiation to repress bone formation, negatively affecting the balance of the bone remodeling process (Zaidi, 2007). Therefore, TNF- $\alpha$ treatment, particularly TNF- $\alpha$ blocking, has been considerably researched as a promising treatment strategy.

Previous studies reported that PGRN plays an important role in the regulation of bone tissue (Noguchi et al., 2015); however, many of these studies concentrated on osteoclasts. As osteoblast differentiation and bone formation also play critical roles in the process of bone remodeling, further studies must be conducted to determine the effect of PGRN on osteoblast differentiation. Another promising method to treat bone loss and increase bone mass is the promotion of bone formation.

The growth factor PGRN has been shown to inhibit TNF- $\alpha$ directly (Liu, 2011; Tang et al., 2011; Hwang et al., 2013); in this study, we explored the blocking effect of PGRN on the TNF- $\alpha$-mediated inhibition of osteoblast differentiation. We established a $\mathrm{C} 2 \mathrm{C} 12$ osteoblast differentiation cell model via BMP-2 induction, where we confirmed that PGRN effectively blocks the TNF- $\alpha$-mediated inhibition of alkaline phosphatase activity and bone mineralization. Furthermore, we discovered that PGRN significantly blocks the inhibitory effect of TNF- $\alpha$ on the expression of osteoblast marker genes such as the genes coding for ColI, Ocn, and Bsp, as well as the expression of Runx2 and Osx. We also determined that PGRN significantly blocks

Genetics and Molecular Research 15 (3): gmr.15038126 
the TNF- $\alpha$-mediated activation of the NF- $\kappa B$ signaling. These results indicate that PGRN effectively blocks the TNF- $\alpha$-mediated inhibition of osteoblast differentiation, and exerts a protective effect on osteoblast differentiation. We speculate that PGRN could be applied for the prevention and treatment of rheumatoid arthritis-induced osteoporosis.

\section{Conflicts of interest}

The authors declare no conflict of interest.

\section{REFERENCES}

Azuma Y, Kaji K, Katogi R, Takeshita S, et al. (2000). Tumor necrosis factor-alpha induces differentiation of and bone resorption by osteoclasts. J. Biol. Chem. 275: 4858-4864. http://dx.doi.org/10.1074/jbc.275.7.4858

Baum R and Gravallese EM (2014). Impact of inflammation on the osteoblast in rheumatic diseases. Curr. Osteoporos. Rep. 12: 9-16. http://dx.doi.org/10.1007/s11914-013-0183-y

Canalis E (1987). Effects of tumor necrosis factor on bone formation in vitro. Endocrinology 121: 1596-1604. http:// dx.doi.org/10.1210/endo-121-5-1596

Chang J, Wang Z, Tang E, Fan Z, et al. (2009). Inhibition of osteoblastic bone formation by nuclear factor-kappaB. Nat. Med. 15: 682-689.http://dx.doi.org/10.1038/nm.1954

Gilbert L, He X, Farmer P, Boden S, et al. (2000). Inhibition of osteoblast differentiation by tumor necrosis factor-alpha. Endocrinology 141: 3956-3964.

Goldring SR and Gravallese EM (2000). Pathogenesis of bone erosions in rheumatoid arthritis. Curr. Opin. Rheumatol. 12: 195-199. http://dx.doi.org/10.1097/00002281-200005000-00006

$\mathrm{He} \mathrm{Z}$, Ong CH, Halper J and Bateman A (2003). Progranulin is a mediator of the wound response. Nat. Med. 9: 225-229. http://dx.doi.org/10.1038/nm816

Huang W, Yang S, Shao J and Li YP (2007). Signaling and transcriptional regulation in osteoblast commitment and differentiation. Front. Biosci. 12: 3068-3092. http://dx.doi.org/10.2741/2296

Hwang HJ, Jung TW, Hong HC, Choi HY, et al. (2013). Progranulin protects vascular endothelium against atherosclerotic inflammatory reaction via Akt/eNOS and nuclear factor-kB pathways. PLoS One 8: e76679.http://dx.doi.org/10.1371/ journal.pone.0076679

Karsenty G, Kronenberg HM and Settembre C (2009). Genetic control of bone formation. Annu. Rev. Cell Dev. Biol. 25: 629-648. http://dx.doi.org/10.1146/annurev.cellbio.042308.113308

Li Y, Li A, Strait K, Zhang H, et al. (2007). Endogenous TNFalpha lowers maximum peak bone mass and inhibits osteoblastic Smad activation through NF-kappaB. J. Bone Miner. Res. 22: 646-655. http://dx.doi.org/10.1359/ jbmr.070121

Liu CJ (2011). Progranulin: a promising therapeutic target for rheumatoid arthritis. FEBS Lett. 585: 3675-3680. http:// dx.doi.org/10.1016/j.febslet.2011.04.065

Noguchi T, Ebina K, Hirao M, Kawase R, et al. (2015). Progranulin plays crucial roles in preserving bone mass by inhibiting TNF-a-induced osteoclastogenesis and promoting osteoblastic differentiation in mice. Biochem. Biophys. Res. Commun. 465: 638-643. http://dx.doi.org/10.1016/j.bbrc.2015.08.077

Pereson S, Wils H, Kleinberger G, McGowan E, et al. (2009). Progranulin expression correlates with dense-core amyloid plaque burden in Alzheimer disease mouse models. J. Pathol. 219: 173-181.http://dx.doi.org/10.1002/path.2580

Tang W, Lu Y, Tian QY, Zhang Y, et al. (2011). The growth factor progranulin binds to TNF receptors and is therapeutic against inflammatory arthritis in mice. Science 332: 478-484. http://dx.doi.org/10.1126/science.1199214

Uccelli A, Moretta L and Pistoia V (2008). Mesenchymal stem cells in health and disease. Nat. Rev. Immunol. 8: 726-736. http://dx.doi.org/10.1038/nri2395

Walsh NCGE and Gravallese EM (2010). Bone remodeling in rheumatic disease: a question of balance. Immunol. Rev 233: 301-312. http://dx.doi.org/10.1111/j.0105-2896.2009.00857.x

Walsh NC, Reinwald S, Manning CA, Condon KW, et al. (2009). Osteoblast function is compromised at sites of focal bone erosion in inflammatory arthritis. J. Bone Miner. Res. 24: 1572-1585.http://dx.doi.org/10.1359/jbmr.090320

Zaidi M (2007). Skeletal remodeling in health and disease. Nat. Med. 13: 791-801.http://dx.doi.org/10.1038/nm1593

Zhao YP, Tian QY, Frenkel S and Liu CJ (2013). The promotion of bone healing by progranulin, a downstream molecule of BMP-2, through interacting with TNF/TNFR signaling. Biomaterials 34: 6412-6421. http://dx.doi.org/10.1016/j. biomaterials.2013.05.030

Genetics and Molecular Research 15 (3): gmr.15038126 